ARTIGO

\title{
Environmental education program in Ecuador: theory, practice, and public policies to face global change in the Anthropocene
}

\author{
Fander Falconí Benítez a \\ Mónica Elizabeth Reinoso Paredes ${ }^{b}$ \\ Javier Collado-Ruano ${ }^{c}$ \\ Edwin Fernando Hidalgo Terán ${ }^{d}$ \\ Gelson David León Ibarra ${ }^{e}$
}

\section{Abstract}

In 2008, the new Constitution of Ecuador recognized the Rights of Nature, in order to restore the ecological footprint. For this reason, the main goal of this article is to reflect about the theories, practices, and public policies developed in Ecuadorian schools with the Environmental Education Program 'Tierra de Todos.' As a result, this work integrates scientific knowledge with ancestral wisdom, combining an ecology of knowledge as a transdisciplinary research methodology. Part of this program is an adaptation of the methodology TiNi and promotes a critical environmental awareness with all students of primary and secondary schools. The methodology TiNi has its origin in Peru and was approved by UNESCO for its potential to learn socio-ecologic didactics in direct contact with nature. As conclusion, environmental education public policies aim to face the complex civilizing challenges of the Anthropocene teaching how to feel-think-act in harmony with the co-evolutionary processes of nature, in order to (re)design regenerative cultures.

Keywords: Anthropocene. Environmental education. Global change. Regenerative cultures. Rights of nature.

\footnotetext{
a Universidad Nacional de Educación, Facultad Latinoamericana de Ciencias Sociales, Ecuador.

b Universidad Tecnológica Indoamérica, Ecuador.

c National University of Education, Ecuador.

d Lingüista, Editor, Ecuador.

e Universidad de las Américas, Ecuador.
} 


\section{Introduction}

The Earth has been deeply modified by human actions during the last centuries. Since the Industrial Revolution, human population has increased until 7.6 billion (UNDESA, 2013). In few generations, humankind has exhausted the fossil fuels that were generated over several hundred million years, resulting in large emissions of air pollutants. The combustion of fossil fuels, along with deforestation, soil erosion, and animal agriculture have increased substantially the atmospheric concentrations of several greenhouse gases -such as carbon dioxide $\left(\mathrm{CO}_{2}\right)$ and methane $\left(\mathrm{CH}_{4}\right)$-, contributing to global warming. That is why many Earth System scientists have concluded that humanity has harvested natural resources in a transcendental manner. The capitalistic socio-economic system conceives nature as an object that provides unlimited raw materials to industrial production models (LEFF, 2002). Capitalism has transformed the ecosystems' geography around the globe resulting in pollution, climate change, ozone layer deterioration, desertification, higher temperatures, depletion of nonrenewable resources, accumulation of radioactive waste, lack of food, proliferation of diseases, water pollution, etc. (CARSON, 1962; KELLERT, 2005; SCHUMACHER, 1973).

For this reason, the environmental speech began rooting in the institutional spheres in 1972, with the United Nations Conference on Human Environment held in Stockholm. In 1977, the UNESCO and the UNEP organized the Intergovernmental Conference on Environmental Education in Tbilisi (Georgia, URSS), to expand its political-educational scope. "Environmental Education should help raise awareness of the economic, political and ecological interdependence of the modern world in order to accentuate the spirit of responsibility and solidarity among nations," says the Tbilisi Final Report (UNESCO, 1978, p.12). After the first stage of conceptualization, environmental education achieved important social and political commitments during the 1980s. The creation of the 'World Commission on Environment and Development' of 1983 was a key event to develop a holistic vision on the environmental problems of our planet. After several years, the commission delivered its first report in 1987, with the title 'Our Common Future'. This document identified the ecological limits for economic growth in industrialized societies, establishing direct links between poverty reduction, gender equity, and redistribution of wealth with environmental conservation strategies. The document was the first to define the term 'sustainable development' as the process that "meets the needs of the present without compromising the needs of future generations" (UNITED NATIONS, 1987).

The final recommendations of the Tbilisi Conference confirmed the inseparable link between the problems of civilization development and environmental 
education. Although this definition of sustainable development is a bit vague and imprecise, environmental educators began to use it to expand a debate about planetary sustainability that still goes on today in formal, informal and non-formal education (ARBOLEDA; PARAMO, 2014; TEITELBAUM, 1978). Regional and international cooperation is a constant in the document to solve the planetary crisis that represents the ecological catastrophe created by humans. Experts recommended rethinking the industrial growth model based on the repudiation of gross domestic product (GDP) as a useful indicator to measure social progress (STIGLITZ; SEN; FITOUSSI, 2010).

According to these economic-mercantile indicators, natural resources such as water, air or land, are not taken into account to measure social development (NEAMAN; OTTO; VINOKUR, 2018), which are obsolete also by excluding environmental health as an essential requirement for preservation, conservation and proliferation of life (RIECHMANN; TICKNER, 2010). Paradoxically, these natural resources are sacred in many ancestral worldwide views of indigenous people from all over the world. In many towns of Abya Yala (original name for Latin America), Mother Earth or Pachamama is conceived as a dynamic organism that is alive: rivers are its veins, mountains are its skin, forests and jungles are its fur, plants are spirits... Under this view, the 2008 Ecuadorian Constitution recognized Nature's Rights at the same hierarchical level as Human Rights. This Constitution is a clear example of knowledge dialogue, where the epistemes of western modern science converged with ancestral wisdom of different people, ethnic groups, cultures, and nations that make up the complexity of this Andean country (COLLADO, 2017).

In this historical context, the reflections of this article are intended to analyze the theory, practice, and public policies of the Environmental Education Program 'Tierra de Todos' developed by the Ministry of Education of Ecuador. First, the theoretical foundations of environmental education are shown. Afterwards, the intercultural, plurinational, and multiethnic nature of the Ecuadorian citizenship is described to understand the environmental practices of those ancient worldviews. Then, good practices of educational intervention through the Equatorial Garden based on the adaptation of the TiNi methodology are explained (ECUADOR, 2017). Finally, quality and innovation courses developed to improve teacher training are presented.

\section{Anthropocene: ecological footprint and global change on earth system}

In the last years, the term 'Anthropocene' has become an important topic in scientific, philosophical, and academic debates. Scientists divide the history of 
our planet into epochs, and we are currently living in the Holocene epoch, a name given to the post-glacial geological period of the past ten to twelve thousand years. However, there is a global debate questioning the huge ecological footprint left by humankind on the Earth. The biologist Eugene Stoermer and the Nobel winning chemist Paul Crutzen advanced the term 'Anthropocene' in 2000, and it has gained acceptance as a new geological period characterized by the influence of human behavior on Earth's atmosphere. Using atmospheric carbon dioxide concentration as a simple indicator to track the pollution acceleration, many researches have proved that our human activities have experienced a great explosion with significant consequences for Earth System functioning. According to Steffen, Crutzen, and McNeil (2007), the Anthropocene began around 1800 with the onset of industrialization, the central feature of which was the enormous expansion in the use of fossil fuels. Then, the concept emphasizes the humankind influence in global geology and ecology, where human actions have a drastic effect on the Earth System.

The term global change refers to changes on planetary scale that occur in the Earth System, encompassing problems as pollution, health, climate, economy, use of natural resources, energy development, transportation, communication, urbanization, land use and coverage, globalization, atmospheric chemistry, oceanic circulation, reduction of water resources, sea level rise, food, loss of biodiversity, overfishing, carbon, nitrogen and water cycles (between other intersystemic and planetary problems) (BOWMAN et al., 2009). As a whole, Earth acts as a meta-system constituted by bio-physical systems that inter-react with each other, giving place to the prevailing global environmental conditions. That is why solutions can't be searched independent from each other, since all the socio-ecological problems of today's world are interdependent (LEFF, 2002; MALO, 2015).

Faced with this ecological and civilizational crisis, the member States of the United Nations agreed to meet eight Millennium Development Goals (MDGs) by 2015. But the efforts were insufficient and, in September 2015, 17 Sustainable Development Goals (SDGs) were approved. The SDGs adopted a renewed biocentric and holistic vision regarding the anthropocentric nature of the MDGs, and established strong links of interdependence between humans and nature. Although the SDGs are not a magic recipe to solve socio-ecological challenges, they constitute a civilizatory meeting point to establish an intercultural dialogue that transgresses the paradigm of current unsustainability (FALCONI, 2014). To better understand the perverse effects of a culture based on the plundering of natural resources, it is necessary to explain the limits of economic growth through 
the concept of ecological footprint. Coined in the 90s by ecologists Rees and Wackernagel, the ecological footprint seeks to:

Account the flows of energy and matter to and from any defined economy and convert them into the corresponding area of land / water required by nature to support these flows (...). This technique is both analytical and educational. It not only assesses the sustainability of current human activities, but is also effective in building public awareness and assisting in decision-making (WACKERNAGEL; REES, 1996, p.3)

Ecological footprint is a biophysical indicator that evaluates sustainability by integrating a set of impacts exerted by a specific human community (city, country or region). It is expressed as the total number of ecologically productive hectares required to produce different products consumed by an average inhabitant of the society analyzed, as well as the area needed to reintegrate and absorb the waste it generates, regardless of the location of this surface. These authors define the biocapacity of a given territory as the biologically productive surface available (forests, crops, pastures, seas, rivers, oceans, etc.). Through the differential calculation between the ecological footprint (demand for resources) and biocapacity (available resources) the ecological deficit is established, which shows whether the studied population has ecological surpluses, or if, on the contrary, it is consuming more natural resources than the ones available. If the latter happens, it shows that the community is degrading the natural capital it has in its territory (compromising its future generations), or is appropriating natural resources that are outside its territorial scope: harming other communities, especially in the so-called 'global South.'

According to estimations of the 2006 report of the Worldwatch Institute, Earth's biocapacity has been plundered around $75 \%$ between China, USA, India, Japan and the European Union. This means that the rest of the countries of the world only have around $25 \%$ of the planetary biocapacity for development. This kind of planetary apartheid requires other forms of wealth distribution, in order to achieve a world that is fairer, more equitable, more democratic and more resilient (COLLADO, 2016). However, when analyzing the differences in the ecological footprint between the richest and the most disadvantaged countries, it is observed that an average person in Bangladesh or Pakistan consumes 0.5 global hectares (hag), while another person in Kuwait uses $10.1 \mathrm{hag}$, and one from the USA consumes around 7 hag. In absolute terms, "it would take 1.5 Earth planets to meet the demands that humanity makes from nature each year" (WWF, 2014, 
p. 9) and "if we lived the lifestyle of a typical US resident, we would need 3.9 planets" (WWF, 2014, p. 36). These statistics speak for themselves about the systematic exploitation to which we are subjecting Earth's ecosystems. It is shocking to note that of the 152 countries included in the study, 91 have a significant biocapacity deficit (WWF, 2014, p. 36). The future is at stake and we cannot fail, we must act quickly and create public policies (NOVICKI; SOUZA, 2010) that transform the socio-ecological metabolism (BOULDING, 1966; DALY, 2014; GEORGESCU-ROEGEN, 1971).

In this sense, the Earth Summit organized in 1992 by the United Nations in Rio de Janeiro, originated the broadest consultation in the history of mankind, between national governments and civil society. From this meeting emerged a commission that drafted the Earth Charter, which was recognized by UNESCO in October 2003. Since then, this document has been used as an educational tool to promote environmental awareness and environmental sustainability within the framework of the 'Decade of the United Nations for Education for Sustainable Development' (UNESCO, 2013). As expressed in the Earth Charter (CTI, 2003, p.1):

We are at a critical moment in the history of Earth, in which humanity must choose its future (...). To move forward, we must recognize that, in the midst of the magnificent diversity of cultures and ways of life, we are a single human family and a single terrestrial community with a common destiny. We must unite to create a sustainable global society based on respect for nature, universal human rights, economic justice and a culture of peace. Humanity is part of a vast evolving universe. Earth, our home, is alive with a unique community of life. The forces of nature promote existence to be a demanding and uncertain adventure, but Earth has provided the essential conditions for the evolution of life. The recovery capacity of the community of life and the welfare of humanity depend on the preservation of a healthy biosphere, with all its ecological systems, a rich variety of plants and animals, fertile lands, pure waters and clean air. The global environment, with its nonrenewable resources, is a common concern for everyone. The protection of Earth's vitality, diversity and beauty is a sacred duty.

With this biocentric, intercultural and transdisciplinary vision, the Earth Charter places special emphasis on the recovery of the community of life, preservation of a healthy biosphere and, moreover, conceives the Earth System as a sacred duty. As a whole, the Charter presents the whole planet as an interconnected 
and indivisible entity, understanding that it is an intimately interrelated and interdependent meta-system that requires complex and systemic solutions to achieve sustainable and regenerative development. For this reason, María Novo (2009) believes that environmental education is a lifelong process and should not be confined solely to the school system curriculum, but should be extended to all areas of non-formal and informal education of society. In the Ecuadorian context, environmental education is a transversal element of the curriculum at all school levels including an intercultural dialogue, through the link with communities, where the educational institutions are attached. As explained below, the Environmental Education Program of the Ministry of Education of Ecuador has a transdisciplinary vision, since common knowledge enriches scientific theories with socio-environmental practices that have proven to be sustainable over time. With this vision rooted in public policies, it is possible to deepen and improve the human-nature relationship, showing the different contexts, realities, interactions and processes.

\section{The recent history of Ecuador: historical, political, and educational context}

To speak about theories, practices, and public policies of Environmental Education in Ecuador means to emphasize that it is a pioneer country in the constitutional recognition of the rights of nature. It is the only country in the world that establishes nature as a subject of law. This legal advancement is a conquest of the people and cultures that, with their different ethnic groups and nationalities, have managed to capture their ancestral worldviews in the Constitution. According to political scientist Acosta (2013), 'Buen Vivir' (Good Living) is a political and philosophical proposal based on Sumak Kawsay, an ancestral Kichwa worldview that understands human beings as an integral and interdependent part of their social and natural environment. This worldview is also known as Suma Qamaña for the Aymara people of Bolivia (TORTOSA, 2009). Therefore, Good Living is the essence of Amerindian indigenous philosophy, which is characterized by its biocentric, intercultural, plurinational, and decolonial vision (WALSH, 2009). This approach is present throughout the Ecuadorian Constitution of 2008 (SIMON, 2013), and in its seventh chapter recognized Nature's rights in the articles 71, 72, 73, and 74 (COLLADO, 2019).

As a whole, the Constitution of 2008 designs the comprehensive exercise of state tutelage over the environment and the co-responsibility of citizens in its preservation, which must be articulated through a decentralized national system of environmental management. That is why public policies for the restoration of nature are oriented towards intersectorial and participatory management of 
shared responsibility. Town halls are the guarantors of deploying (eco)efficient mechanisms in their respective management areas, but private industrial sectors must also assume their role in accordance with socio-environmental welfare. In this way, an inter-institutional governance that replaces the anthropocentric vision of the traditional economy is proposed, and it seeks to consolidate itself from a biocentric conception that restores and regenerates ecosystems (COLLADO, 2019). In total, the Ministry of Environment of Ecuador (MAE) estimates that there are some 4,800 species (fish, amphibians, reptiles, birds and mammals) throughout the country, which is why Ecuador is known as a mega-diverse country (ECUADOR, 2015).

Regarding its cultural diversity, Ecuador is characterized as an intercultural and multi-ethnic country, where different nationalities coexist. According to data from the 2010 Census (INEC, 2010), the inhabitants of Ecuador self-identify according to customs and traditions in 45 ethnic groups (mestizos, indigenous, Afro-Ecuadorians and whites) distributed by coast, highland, amazon and insular regions. Article 56 reminds us that "the communities, people, and indigenous nationalities, the Afro-Ecuadorians, the Montubios and the communes are part of the unique and indivisible Ecuadorian State." This ethnic diversity is grouped into 14 nationalities and 20 groups, who speak 14 languages throughout the territory (ECUADOR, 2009). The flourishing of citizen interculturality entails the overcoming of the historical exclusion imposed by coloniality (QUIJANO, 2000). In short, the will of the constitution is national unity through the democratic recognition of intercultural, plurinational and multi-ethnic richness (WALSH, 2009).

At the same time, the Ecuadorian Constitution considers that education is a human right and a priority area of public policy to ensure equity and social inclusion. The promotion of models, research and educational practices are conceived as scenarios of intercultural, plurinational and multi-ethnic encounters, where mutual respect and recognition are the basis for the multidimensional construction of the Ecuadorian identity (ECUADOR, 2013, p. 158). In this context, the axis of epistemic enunciation of public environmental education policies developed by the Ministry of Education of Ecuador, in collaboration with other national and international institutions, has a marked intercultural character that includes and integrates scientific knowledge with ancient knowledge of indigenous people (KRAINER, 2012). In this way, the transdisciplinary approach to environmental education implies an inter-epistemological dialogue of ancestral knowledge with the natural sciences, social sciences, mathematics, arts and humanities, geosciences and telecommunications. As shown in Figure 1, the transversalization of the environmental education axis is based on a multidimensional dialogue that germinates both the scientific knowledge and the common knowledge. 


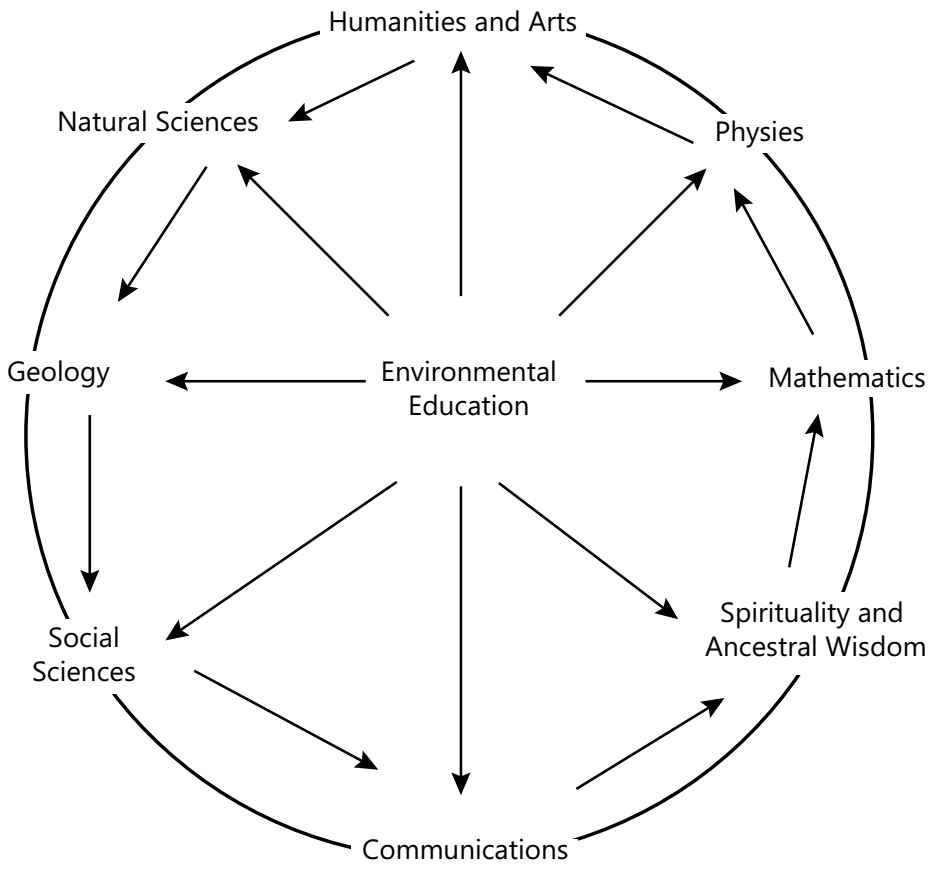

Source: Collado (2019, p. 60).

Figure 1. Transdisciplinary dialogue of Environmental Education.

Environmental Education combines the inside and outside dimensions of human training. By approaching the basics of environmental education in a transdisciplinary way, the teaching-learning processes are significantly enriched, as their formative dimensions fertilize each other and lead to new ways of feeling-thinking-acting with Pachamama (COLLADO, 2017). Rooting theoretically, methodologically and pragmatically, the transversalization of environmental education in the Ecuadorian education system has involved a profound reflection on the processes of human formation. These reflections have identified and developed in a multidimensional way the competencies, skills, attitudes and skills necessary to face the global change (ECUADOR, 2018a). In this sense, the solutions proposed by Ecuador on an international scale are all mitigations, but they are indispensable to avoid a greater evil. It has been proposed to transform the productive matrix of an ecocide capitalism by a circular economy, stopping the economic growth that entails the consequent loss of natural heritage. It has also been proposed to achieve social and environmental justice, modify environmental governance, change the rules of the international financial system, create an international environmental tribunal, unite the countries 
of the global South, demand the payment of environmental debt, modify the environmental problem metric, promote the entrepreneurial spirit, and reinforce environmental education programs (FALCONI, 2017).

In this way, the foundations and basic principles of environmental education go hand in hand with public policies that favor the emergence of an ecological economy focused on achieving sustainable, resilient and regenerative development (COLLADO; MADROÑERO; ALVAREZ, 2018). Political commitment is a primary factor to transform the productive matrix, as well as the mentality of individuals and the collective imagination of our societies. For this reason, it is urgent for the globalized society of the 21st century to become aware of the socioeconomic unsustainability of industrialization, whose patterns of consumption and production put at risk both future human generations and the rest of natural ecosystems. This problem of civilizational unsustainability has been studied in recent years by great historians, philosophers, economists, sociologists, ecologists, biologists, geographers and anthropologists. Here we can highlight the ideas of thinkers such as Joan Martinez-Alier (2011), Kenneth Boulding (1966), Rachel Carson (1962), Herman Daly (2014), Nicholas Georgescu-Roegen (1971), Karl Kapp (1975), Aldo Leopold (1989), Howard T. Odum (2007), Karl Polanyi (2001), Arne Naess (1989) and EF Schumacher (1973) among many others. All made us understand the limits of biophysical regeneration of our planet, in order to transform the capitalist system that guides our civilization.

Undoubtedly, reflecting on the future of humanity entails questioning our relationship with nature. Several scientific studies estimate that, in the short period from 1990 to 2020, between $10 \%$ and $38 \%$ of planetary biodiversity will disappear (OBERHUBER, 2004). According to Leakey and Lewin (1996), capitalism has caused the global change of the Anthropocene, provoking the mass 'sixth extinction' of living beings. Facing the global change provoked by capitalism requires transgressing the failed theoretical model of sustainable development established by the academic discourse of technoscience. While the concept of sustainable development is focused on minimizing the negative impact of humans on the planet, regenerative development focuses on maximizing the positive impact of human beings on Earth (ORR, 2002; PAULI, 2015; WAHL, 2016).

This regenerative approach represents a qualitative leap in our relations with nature, in harmony with the biocentric vision of restoration embodied in the Constitution of 2008. Overcoming the current ecological footprint requires adopting the wisdom and creativity inherent in nature to create new, more resilient futures (BENYUS, 2012; RIECHMANN, 2014). That is why it is urgent to introduce this regenerative 
vision, of restoration of nature, of ecological economy in public education policies, in order to transform our production and consumption habits that deplete planetary ecosystems. In this direction, the Equatorial Garden implemented in more than 10,000 schools in Ecuador described below, is advancing.

\section{An adaptation of the TiNi methodology to promote environmental consciousness}

Environmental consciousness is present in many worldviews of Amerindian indigenous people, who understand the sacred attribute of nature as a spiritual connection. Just as no one learns to swim out of water, no one learns to love nature without being in direct contact with it. For this reason, the 'Land of Girls, Boys and Children' (TiNi) methodology was adopted in Ecuador, to achieve the Good Living (ECUADOR, 2017). This methodological innovation is the result of the cooperation between the Ministry of Education of Ecuador with: 1) UNESCO in Quito (headquarters for Bolivia, Colombia, Ecuador and Venezuela), and 2) the Association for Children and their Environment ANIA, chaired by Joaquín Leguía. In 2012, the TiNi Methodology was recognized by UNESCO as a good education practice to raise environmental awareness. According to Leguía and Paredes (2016, p.24):

A TiNi is a space granted by adults to girls, boys and young people, from half a square meter of land, where with love, they grow life and biodiversity; and in the process they strengthen their knowledge, skills, values, and self-esteem to live in harmony with the environment.

With this educational vision of human training, the Ministry of Education of Ecuador in 2017 recognized the TiNi methodology as a good educational practice and a fundamental pedagogical resource for the transversalization of the environmental axis within the framework of public policies of the Environmental Education Program 'Tierra de Todos.' Within the TiNi space, the actions that are carried out should be focused on the benefit of the children, their families or their communities and, of course, nature itself. The goal of the TiNi methodology is to put girls and boys in regular contact with nature from an emotional approach (LEGUIA; PAREDES, 2016). Girls, boys and young people from any country can implement the TiNi methodology regardless of their socio-economic or cultural situation, in a rural or urban area, in their schools, homes or communities. This methodology has already been implemented in more than 10 countries, and 
can be developed both in small areas from half a square meter or in large areas (mountains, jungles, valleys, etc.) (LEGUIA, 2017).

Through this methodology, students can learn competences, skills and values for sustainable and regenerative management of natural resources. In this process to value nature, culture and identity is learned, developing, in addition, feelings of affection for all forms of life (ECUADOR, 2018b). According to Leguía (2017), with this methodology empathy and solidarity with other people, as well as the self-esteem of students, are improved. In short, it is a methodology focused on tackling global change through direct action-theory learning in the cultivation and restoration of ecosystems. Also, the TiNi methodology has shown that it can be very useful for environmental management, since it favors the care of ecosystems and develops multilevel actions among students and their communities.

The adaptation of the TiNi methodology to the Ecuadorian context is also known as the Equatorial Garden, and was made within the public policies framework of the Environmental Education Program 'Tierra de Todos' of the Ministry of Education, in collaboration with other public and private institutions of national and international scopes. The main objective of this program is to strengthen environmental awareness and promote a regenerative culture throughout the educational community. Through a biocentric approach based on values, ethical orientation, altruism, innovation and education quality, the program seeks to integrate and transversalize environmental education at all school levels, in order to make the Ecuadorian citizens responsible for the social challenges of global change. In this direction, the Program is developed in three areas:

1. Implementation of innovative pedagogical methodologies with an affective, playful, practical, intercultural, transdisciplinary, and holistic approach.

2. Strengthening the national curriculum with an environmental approach.

3. Good environmental practices in the education system.

In 2018, the National Education System of Ecuador had a total of 15,365 schools. This represents a great challenge for the successful implementation of the three lines of action that define the environmental education public policies present in the Program. The Ecuadorian version of TiNi, like every plant transplanted to other lands, has shaped its own idiosyncrasy. On September 21, 2017, the Ministry of Education issued the guidelines for the implementation of this methodology at 
national level (Ministerial Agreement No. 0082-A, 2017) and, as of June 2018, 10,021 schools had inaugurated their own TiNi spaces (ECUADOR, 2018b).

In total, more than 2.6 million students and 161,500 teachers benefit from the Equatorial Garden, which already has an extension of more than $1,000,000 \mathrm{~m}^{2}$ for environmental protection and the implementation of environmental education (ECUADOR, 2018b). Among the most illustrative examples, there is a school of three hectares, whose crops already provide food for students and teachers, purify the air their community breathes and offers the necessary habitat for the development of life. There is another school in old Cuenca, the third largest city in the country, which made a micro reproduction of the hanging gardens of Babylon. In turn, there are also other small schools located in urban areas that barely reach the square meter.

For the implementation of the methodology at national level, the Ministry of Education (ECUADOR, 2017) issued the 'Introductory Guide to the Methodology Land of Girls, Boys and Youth for Good Living-TiNi,' in order to implement it in K12 schools. This guide explains the importance of respecting the particularities of each school, its territorial environment and its cultural realities. Good practices of educative intervention for the Equatorial Garden have also been achieved with training for more than 2,559 teachers from all over the country.

Through the periodic contact with nature, proposed by the TiNi methodology, teachers of Ecuador have begun to transversalize environmental education in all subjects, identifying environmental problems that afflict the educational community and seeking solutions to them. This space allows to enrich theories in mathematics, social studies, language and communication, natural sciences and other subjects. Teachers materialize the theoretical knowledge offered in classrooms, in a natural space, recognizing students as agents of change that shape their realities day by day with actions that benefit themselves, others and nature.

With regard to the axis of strengthening the national curriculum with an environmental approach, an Advisory Committee was set up to implement the Program, composed by the Ministry of Environment, Amazon Regional University IKIAM, National Education University-UNAE, General Directorate of Maritime Interests of the Navy, and the Ministry of Education. In the course of 2017-2018, four meetings of the Advisory Committee have been developed and have served to establish the conceptual bases for the transversalization and strengthening of good environmental practices in the different levels of the current school curriculum. In addition, two online courses on quality and innovation in 
environmental education have been created to improve the training of 165,000 teachers throughout the country between 2018 and 2021 (ECUADOR, 2018b). Its conceptual, procedural, and attitudinal contents place special emphasis on the foundations of environmental education, environmental regulations in Ecuador, natural heritage, climate change, environmental quality, maritime awareness and the creation of environmental projects in schools through the TiNi methodology.

As it was already mentioned, the third axis of the Program consists of the implementation of good environmental practices. The Manual of Good Environmental Practices for Schools (ECUADOR, 2018a) aims to raise awareness and involve the community in the care and protection of the environment through the dissemination and exercise of good environmental practices. Good environmental practices are actions, practical advices and teaching resources aimed at generating changes in consumption habits and lifestyles, in order to promote responsible consumption and to (re)design regenerative cultures. As explained in the Report of the Environmental Education Program 'Tierra de Todos' (ECUADOR, 2018b), there are multiple good environmental practices experiences throughout the country that have implemented innovative pedagogical methodologies with an affective, playful, practical, intercultural, transdisciplinary and holistic approach. This means that there has been a great reception by the entire community, which seeks to enrich their knowledge and apply what they have learned in their classes.

As a whole, the three action areas of the Program 'Tierra de Todos' have yielded successful and hopeful results. Although it is soon to bring more complete results, the indicators and evaluators of each line of action indicate that the Equatorial Garden has reported multiple benefits. This adaptation of the TiNi methodology has created an inclusive environment that reinforces the interaction between students, teachers, family and community, generating collective environmental awareness. Direct contact with nature has also brought benefits to the health of communities, whose teaching-learning processes have allowed the abstract (theory) to become concrete (practical), and the knowledge and skills acquired have one purpose: environmental care. In the coming years, we expect to obtain broader results that would allow us to better understand the impact of public policies implemented within the framework of the Environmental Education Program 'Tierra de Todos.'

\section{Conclusions to (re)design regenerative cultures}

Education is key to achieving a sustainable and regenerative development for the Earth System: being the seed that we must cultivate for our present and future 
flourishing. Environmental Education cannot be just about transmitting values and knowledge, but is a creative, constructive and transformative act. Ecuadorian students must learn to develop a continuous self-conscious dialogue to feel-think-act with their emotional feelings, thoughts, and actions. In fact, sustainable and regenerative development is not only a quantifiable issue in economic terms, but also a human quality of feeling-thinking-acting in harmony with the Pachamama (COLLADO, 2017). For this reason, it is urgent to create public policies aimed at conservation, preservation, and remediation of ecosystems, in order to (re) design regenerative cultures that transform the current civilizatory direction.

As has been presented throughout this work, the public policies developed within the framework of the Environmental Education Program 'Tierra de Todos' are aimed at the regenerative development of nature. The great asymmetry and economic inequality that globalization produces translates into planetary unsustainability and puts at risk the existence of future generations, especially in the so-called 'global South.' That is why it is essential to reflect on the role of public policies on Environmental Education as a transversal element in human training, both in Ecuador and other countries. The partial results that have been obtained from the implementation of the program presented show the need to continue working on teacher training, strengthening the quality and innovation of the school curriculum and promoting good environmental practices.

Finally, it must be emphasized that since the 1990s the limits of biophysical regeneration of nature have been exceeded. We did not put limits on economic growth and that has translated into a systematic spoliation of natural resources. That is why it is urgent to overcome the discourse of sustainable development in order to move towards a regenerative development, as inspired by the 2008 Ecuadorian Constitution (ECUADOR, 2008). The technological energy efficiency is no longer useful by itself, because global change is irreversible. An important response to this civilizatory crisis is environmental education. When people's emotions are appealed, fundamental collective environmental awareness is constructed to build more resilient futures. Environmental education is an essential seed to raise awareness to comply with the SDGs. Although environmental education does not transform the productive matrix in a direct way, it helps to form regenerative cultures through collective environmental awareness. In short, public policies concerning environmental education must teach us to protect the environment, mitigate the effects of global change, and remedy the negative impacts on nature. Environmental education teaches us solidarity, encourages us to actively participate in the changes needed to save the planet. Are we ready? This article is a call for an active citizen participation to sow environmental conscience that derives in restoration actions of Mother Earth. 


\section{Programa de educação ambiental no Equador: teoria, prática e políticas públicas para enfrentar a mudança global do Antropoceno}

\section{Resumo}

Em 2008, a nova Constituição do Equador reconheceu os Direitos da Natureza para restaurar a pegada ecológica. Por esse motivo, o objetivo principal deste artigo é refletir sobre as teorias, práticas e politicas públicas desenvolvidas nas escolas equatorianas com o Programa de Educação Ambiental 'Terra de Todos'. Como resultado, este trabalho integra o conhecimento científico com a sabedoria ancestral, combinando uma ecologia de saberes como uma metodologia de pesquisa transdisciplinar. Parte deste programa é uma adaptação da metodologia TiNi e promove uma consciência ambiental crítica com todos os estudantes das escolas primárias e secundárias. A metodologia TiNi tem a sua origem no Peru e foi aprovada pela UNESCO pelo seu potencial para aprender didáticas socio-ecológicas em contato direito com a natureza. Em conclusão, as políticas públicas de educação ambiental estão destinadas a combater os complexos desafios civilizatórios do Antropoceno para ensinar sobre como sentir, pensar e agir em harmonia com os processos co-evolutivos da natureza, com o fim de (re)desenhar culturas regenerativas.

Palavras-chave: Antropoceno. Educação ambiental. Mudança global. Culturas regenerativas. Direitos da natureza.

\section{Programa de educación ambiental en Ecuador: teoría, práctica y políticas públicas para enfrentar el cambio global del Antropoceno}

\section{Resumen}

En 2008, la nueva Constitución del Ecuador reconoció los Derechos de la Naturaleza para restaurar la huella ecológica. Por este motivo, el objetivo principal de este artículo es reflexionar sobre las teorías, prácticas y políticas públicas desarrolladas en las escuelas ecuatorianas con el Programa de Educación Ambiental 'Tierra de todos'. Como resultado, este trabajo integra el conocimiento científico con la sabiduría ancestral, combinando una ecología de saberes como metodología de investigación transdisciplinar. Parte de este programa es una adaptación de la metodología TiNi y promueve una conciencia ambiental crítica con todos los estudiantes de escuelas primarias y secundarias. La metodología TiNi tiene su origen en Perú y fue aprobada por la UNESCO por su potencial para aprender didácticas socio-ecológicas en contacto directo con la naturaleza. Como conclusión, las políticas públicas de educación ambiental apuntan a enfrentar los complejos desafios civilizatorios del Antropoceno enseñando sobre cómo sentir, pensar y actuar en armonía con los procesos co-evolutivos de la naturaleza, con el fin de (re)diseñar culturas regenerativas.

Palabras clave: Antropoceno. Educación ambiental. Cambio global. Culturas regenerativas. Derechos de la naturaleza. 


\section{References}

ACOSTA, A. El Buen Vivir. Sumak Kawsay, una oportunidad para imaginar otros mundos. Barcelona: Icaria, 2013.

ARBOLEDA, I.; PÁRAMO, P. La investigación en educación ambiental en América Latina: un análisis bibliométrico. Revista Colombiana de Educación, Bogotá, n. 66, p. 55-72, ene-jun. 2014.

BENYUS, J. Biomímesis: cómo la ciencia innova inspirándose en la naturaleza. Barcelona: Tusquets, 2012.

BOULDING, K. La economía de la venidera nave especial Tierra. Michigan: Boulding Papers, 1966.

BOWMAN, D. et al. Fire in the earth system. Science, v. 324, n. 5926, p. 481-4, 2009. https://doi.org/10.1126/science.1163886

CARSON, R. Silent spring. New York: Houghton Mifflin, 1962.

CARTA DE LA TIERRA INTERNACIONAL - CTI. La Carta de la Tierra. San José, 2003.

COLLADO, J. Big history in the ecuadorian educational system: theory, practice, and public policies of environmental eduation. Journal of Big History, v. 3, n. 2, p. 49-66, 2019. https://doi.org/10.22339/jbh.v3i2.3250

. Educación ambiental en Ecuador: reflexiones bioalfabetizadoras para el desarrollo sostenible. In: Martinez, M. (Coord.). Visiones de sostenibilidad. México, DF: UASLP, 2017. p. 307-26.

. La huella socioecológica de la globalización. Sociedad y Ambiente, Chiapas, v. 11, p. 92-121, jul.-oct. 2016.

COLLADO, J.; MADROÑERO, M.; ÁLVAREZ, F. Educación transdisciplinar: formando en competencias para el buen vivir. Ensaio: Avaliação de Políticas Públicas em Educação, Rio de Janeiro, v. 26, n. 100, p. 619-44, jul.-set.2018. https://doi.org/10.1590/s0104-40362018002601487

DALY, H. From uneconomic growth to a steady-state economy. Northampton: Edward Elgar, 2014.

ECUADOR. Asamblea Nacional. Constitución de la República del Ecuador. Quito, 2008. 
ECUADOR. Ministerio Coordinador del Patrimonio Humano - MCP. Plan Plurinacional para Eliminar la Discriminación Racial y la Exclusión Étnica y Cultural 2009-2012. Quito: Ministerio Coordinador del Patrimonio Humano, 2009.

. Ministerio de Ambiente del Ecuador - MAE. Quinto Informe Nacional para el Convenio sobre la Diversidad Biológica. Quito: MAE, 2015.

. Ministerio de Cultura del Ecuador - MCE. Universidad de las artes. Proyecto emblemático de la Revolución Cultural. Quito: Ministerio de Cultura, 2013.

Ministerio de Educación del Ecuador - MinEduc. Guía Introductoria a la metodología TiNi: tierra de niñas, niños y jóvenes para el Buen Vivir. Quito: Mineduc, 2017.

. Ministerio de Educación del Ecuador - MinEduc. Manual de buenas prácticas ambientales para instituciones educativas. Quito, 2018a. . Ministerio de Educación del Ecuador - MinEduc. Memoria de sostenibilidad del Programa de Educación Ambiental "Tierra de Todos". Quito: MinEduc, 2018b.

FALCONÍ, F. Al sur de las decisiones: enfrentando la crisis del siglo XXI. 1. Quito: El Conejo, 2014.

FALCONÍ, F. Solidaridad sostenible: la codicia es indeseable. Quito: El Conejo, Quito, 2017.

GEORGESCU-ROEGEN, N. The entropy law and the economic process. Cambridge: Harvard University Press, 1971.

INSTITUTO NACIONAL DE ESTADÍSTICA Y CENSO - INEC. Censo 2010: población y vivienda: una historia para ver y sentir. Quito: INEC, 2010.

KAPP, K. The social costs of private enterprise. New York: Schocken, 1975.

KELLERT, S. Building for life: designing and understanding the human-nature connection. Washington, DC: Island Press, 2005.

KRAINER, S. (coord.). Educación, interculturalidad y ambiente: experiencias prácticas en centros educativos en Ecuador. Quito: Flacso, 2012. 
LEAKEY, R.; LEWIN, R. The sixth extinction: biodiversity and its survival. Nairobi: Phoenix, 1996.

LEFF, E. Saber ambiental: sustentabilidad, racionalidad, complejidad, poder. México: Editorial Siglo XXI, 2002.

LEGUÍA, J. El eslabón perdido para un mundo sostenible. Lima: ANIA, 2017.

LEGUÍA, J.; PAREDES, N. Guía para docentes de cómo aplicar la metodología TiNi. Lima: ANIA, 2016.

LEOPOLD, A. A Sand County Almanac and sktches here and there. Oxford: Oxford University Press, 1989.

MALO, A. El metabolismo social, el Sumak Kawsay y el territorio: el caso de Cuenca, Ecuador". 2015. 284 p. Tesis (Doctoral en Disciplina) Universidad Autónoma de Barcelona, Barcelona, Espanha, 2015.

MARTÍNEZ-ALIER, J. El ecologismo de los pobres: conflictos ambientales y lenguajes de valoración. Barcelona: Icaria, 2011.

NAESS, A. Ecology, community, and lifestyle: outline of an ccosophy. Cambridge: Cambridge University Press, 1989.

NEAMAN, A.; OTTO, S.; VINOKUR, E. Toward an integrated approach to environmental and prosocial education. Sustainability, v. 10, n. 3, p. 583, Mar. 2018. https://doi.org/10.3390/su10030583

NOVICKI, V.; SOUZA, D. Políticas públicas de educação ambiental e a atuação dos Conselhos de Meio Ambiente no Brasil: perspctivas e desafios. Ensaio: Avaliação de Políticas Públicas em Educação, Rio de Janeiro, v. 18 , n. 69 , p. 711-736, out.-dez. 2010. https://doi.org/10.1590/S010440362010000400004

NOVO, M. El desarrollo sostenible: su dimensión ambiental y educativa. Madrid: Ed. Universitas, 2009.

OBERHUBER, T. Camino de la sexta gran extinción. Madrid: Ecologistas en Acción, 2004. (Ecologista, vol 41).

ODUM, H. Environment, power and society. New York: Columbia University Press, 2007. 
ORGANIZAÇÃO DAS NAÇÕES UNIDAS PARA A EDUCAÇÃO, A CIÊNCIA E A CULTURA - UNESCO. Intergovernmental Conference on Environmental Education. Tbilisi (USSR): final report. Paris, 1978.

. Década de las Naciones Unidas por la Educación para el Desarrollo Sostenible. Paris, 2013.

ORR, D. The nature of desing: ecology, culture, and human intention. Oxford: Oxford University Press, 2002.

PAULI, G. La economía azul: 10 años, 100 innovaciones, 100 millones de empleos. Barcelona: Tusquets, 2015.

POLANYI, K. The great transformation: the political and economic origins of our time. Boston: Beacon Press, 2001.

QUIJANO, A. Colonialidad del poder, eurocentrismo y América Latina. In: LANDER, E. (Comp.). La colonialidad del saber: eurocentrismo y ciencias sociales: perspectivas latinoamericanas. Buenos Aires: CLACSO, 2000. p. 201-46.

RIECHMANN, J. Un buen encaje en los ecosistemas. 2. ed. Madrid: Ed. Catarata, 2014.

RIECHMANN, J.; TICKNER, J. (Coords). El principio de precaución: en medio ambiente y salud pública: de las definiciones a la práctica. Barcelona: Icaria, 2010.

SCHUMACHER, E. Small is beautiful: a study of economics as if people mattered. London: Blond and Briggs, 1973.

SIMON, F. Derechos de la naturaleza: ¿Innovación trascendental, retórica jurídica o proyecto político? Iuris Dictio, Quito, v. 15, 9-38, ene.-jun. 2013.

STEFFEN, W.; CRUTZEN, P.; McNEILL, J. The anthropocene: are humans now overwhelming the great forces of nature? AMBIO, v. 36, n. 8, p. 614-21, Dec. 2007.

STIGLITZ, J., SEN, A.; FITOUSSI, J. Mis-measuring our lives. why GDP doesn't add up: the report by the Commission on the Measurement of Economic Performance and Social Progress. New York: New Press, 2010. 
TEITELBAUM, A. El papel de la educación ambiental en América Latina. París: Unesco, 1978.

TORTOSA, J. M. Sumak Kawsay, Suma Qamaña, buen vivir. Madrid: Fundación Carolina, 2009.

THE UNITED NATIONS DEPARTMENT OF ECONOMIC AND SOCIAL AFFAIRS - UNDESA. Population Division. World population prospects 2012 revision. New York, 2013.

UNITED NATIONS. Report of the World Commission on Environment and Develoment. "Our Common Future". New York, 1987.

WACKERNAGEL, M.; REES, W. Our ecological footprint. reducing human impact on the earth. Gabriola Island: New Society, 1996.

WAHL, D. Designing regenerative cultures. Axminster: Triarchy, 2016.

WALSH, C. Interculturalidad, estado, sociedad: luchas (de) coloniales de nuestra época. Quito: UASB/Abya-Yala, 2009.

WORLDWATCH INSTITUTE. State of the World 2006: special focus: China and India. Washington: Island Press, 2006.

WORLD WILDLIFE FUND - WWF. Living planet report 2014: species and spaces, people and places. Washington, DC, 2014. 


\section{Informações dos autores}

Fander Falconí Benítez: PhD. Teacher-researcher of the Latin American Faculty of Social Sciences (FLACSO - Ecuador) and the National University of Education (UNAE) of Ecuador. PhD in Environmental Sciences, with specialization in Ecological Economics and Environmental Management from the Autonomous University of Barcelona. Former Minister of Education of Ecuador. Contato: ffalconi@flacso.edu.ec

iD https://orcid.org/0000-0001-5594-7267

Mónica Elizabeth Reinoso Paredes: Teacher-researcher at the Universidad Indoamérica, Ecuador. Director of the TiNi Global Network, Former Vice-Minister of Educational Management of Ecuador. Master in Business Administration from SEK International University of Ecuador. She has a Higher Diploma in Design, Management and Evaluation of Development Projects by FLACSO-Ecuador and carried out the Sustainability Management Program of INCAE Business School. Contato: moni_reinoso@hotmail.com

iD https://orcid.org/0000-0002-8353-4600

Javier Collado-Ruano: PhD. Teacher-researcher of the National University of Education (UNAE) of Ecuador. PhD in Dissemination of Knowledge (UFBA, Brazil) and PhD in Philosophy (USAL, Spain). Master in Education (U. Sevilla, SPAIN). Degree in History (U. Valencia, Spain), with specialization in International Relations and Archeology

(U. Degli Studi di Palermo, Italy). Contato: javier.collado@unae.edu.ec

iD https://orcid.org/0000-0003-0063-6642

Edwin Fernando Hidalgo Terán: Linguist, writer, and journalist. Contato: efht1954@gmail.com

iD https://orcid.org/0000-0001-5935-4848

Gelson David León Ibarra: Environmental Engineer in Prevention and Remediation from the Universidad de las Américas-Ecuador. Winner of "Project citizen" of Woodland Joint Unified School District, CA. Contato: gelson21david@gmail.com

iD https://orcid.org/0000-0002-4082-2119 